INTERNATIONAL JOURNAL FOR

HISTORY, CULTURE AND MODERNITY

www.history-culture-modernity.org

Published by: Uopen Journals

Copyright: @ The Author(s).

Content is licensed under a Creative Commons Attribution 4.0 International Licence

elSSN: 2213-0624

\title{
Formations of European Modernity
}

Cosmopolitanism, Eurocentrism and the Uses of History

\section{Patrick Pasture}

HCM 3 (1): 73-90

URN:NBN:NL:UI:10-1-117039

\begin{abstract}
In Formations of European Modernity, Gerard Delanty, one of the foremost social theoreticians of Europe, offers a historical-sociological assessment of the idea of Europe as the development of modernity from a cosmopolitan perspective. With this book, based upon a broad and impressive discussion of sociological and historical literature, Delanty somewhat comes back from his earlier constructivist approach in favour of a theory that emphasizes the originality of Europe and assesses European history as the development of modernity, interpreted in a classical neoWeberian sense. This approach sits uneasily with his ambition to present a cosmopolitan view on Europe, which emphasizes the interactions of Europe with the rest of the world, all the more so as he largely ignores the postcolonial critiques of Eurocentric narratives as well as modernization theories. While Delanty is still quite successful in his assessment of historical diversities in Europe, Formations of European Modernity nevertheless disappoints. While the focus on global interactions is highly commendable, the lack of critical assessment and contextualization leads to a neglect of the fact that Europe often despised the (contribution of the) other. Hence his presentation of cosmopolitan Europe is flawed, and remains if not Eurocentric at least overly Europhile.
\end{abstract}

Keywords: modernity, globalization, cosmopolitanism, European history, European identity

Review essay of Gerard Delanty, Formations of European Modernity. A Historical and Political Sociology of Europe (Houndmills: PalgraveMacmillan, 20I3) 352 pp., ISBN 978 I I37287908. 
Instead, the only lesson seemingly to be learnt by Europeans from their experience of what Habermas and Derrida call the 'bloom' of imperialism is the ability to 'assume a reflexive distance from themselves', a distance which does not seem to provide reflections upon themselves.

\section{Revisiting 'Inventing Europe'}

Gerard Delanty, professor of sociology at the University of Sussex, is one of the foremost social theoreticians of Europe today. His book Inventing Europe: Idea, Identity, Reality (1995) is one of the rare sociological studies that has had a wide reading among historians because of the constructivist discussion of European identity. His approach seems to correspond to historical discussions of questions of collective identity inspired by cultural theory - social science and cultural theory become very close in this particularly inspiring book. ${ }^{2}$ More recently Delanty has become one of the leading theoreticians of cosmopolitanism, in which he not only rethinks the place of nations and Europe in a world of increasing connectivities, transnational organizations and global forces, but emphasizes 'the capacity of self-problematization and new ways of seeing the world', in particular 'the critical and reflexive consciousness of heterogeneity as opposed to the quintessential modernist spirit of an homogenous vision of sovereign statehood'. ${ }^{3}$ If Delanty publishes a new book, especially with the most promising title Formations of European Modernity: A Historical and Political Sociology of Europe, it really is something to look forward to: he seems to be one of those rare sociologists who is able to bridge the gap between sociology and history. The book is also presented as an interdisciplinary endeavour.

Formations of European Modernity started as a new edition of his earlier classic Inventing Europe but resulted in a totally new and particularly ambitious book in which the author aims at discussing Europe in its global and historical context, moving away from the emphasis on the question of the waning of the nation-state and the parallel emergence of new transnational associations and a European 'super-state', towards a 'cosmopolitan' focus on global justice, governance and the social transformations resulting from more complex globalization processes. Surprisingly however, Delanty confesses to going back on his 
constructivist approach which, in his own words, was 'useful for the critical purpose of unmasking the "Grand Narratives" of history' but risks leading to 'fairly simplistic arguments and polemical positions' (x). It is rare to see a scholar so explicitly renounce some of his or her earlier work - especially as there was nothing simplistic in the way he made his case before - and it reveals a most commendable courage. But the move raises questions nevertheless - what does he actually mean by these 'simplistic arguments and polemical positions'? Here, as elsewhere in the book where one finds similarly strong statements condemning work done by others, the author remains remarkably uncommunicative, leaving the reader the task of finding examples.

The question returns when Delanty refers to Dipesh Chakrabarty's famous call to 'provincialize' Europe, which he interprets as not viewing Europe 'as a normative or evaluative reference point for all parts of the world; in other words it should be discovered as it is'. One may wonder what the latter might mean, as it conspicuously recalls Ranke's 'wie es eigentlich gewesen' [what actually happened] - and if there is one thing that can be concluded from Delanty's assessment, it is that his history is all but 'Rankean'. The following sentence increases the feeling of uneasiness that begins to creep into the reading of the book: "Provincializing Europe" is a demonstration of the limits of the global relevance of Europe without denying the validity of many of its achievements or the possibility of internal logics of development' (7, emphasis added). While Chakrabarty explicitly opposes the cultural relativism that the title of his own book seems to suggest, 'without denying the validity of many of its achievements' does not constitute the core of Chakrabarty's argument either. It slowly dawns on the reader that Delanty's aim is somehow to 'redress the balance' of the postcolonial and historical critique of Eurocentric narratives reminiscent of how some in the US oppose historical 'revisionism' that 'emphasizes negative aspects of our nation's history while omitting or minimizing positive aspects'. ${ }^{4}$ Delanty, too, explicitly opposes a narrative that in his eyes overly stresses the 'dark side' of European history. ${ }^{5}$ Although he corroborates the ambition to "counter-act the rosy picture of the rise of Europe and the uncritical celebrations of its achievements', he states that such histories will not help explaining 'the specificity of Europe' (5). Why the specificity of Europe should 
reside only in positive features remains a mystery - and a most questionable argument.

\section{European Modernity}

Delanty uses modernity as the central framework in understanding the historical development of Europe both in its unity and its diversity. However, as readers of this journal will certainly be familiar with, the concept has been hotly debated, particularly since the I99os (once again, one should say, as debates on the concept of modernity tend to return with the regularity of spring blossoms and autumn colours). Scholars in the wake of Max Horkheimer and Theodor W. Adorno actually argue that in whatever way modernity is defined - as an intellectual story of progress, rationalization and enlightenment or in terms of social processes of urbanization, functional differentiations and the like - European or western history cannot be regarded as a simple road, let alone a smooth one, towards progress. ${ }^{6}$ Postcolonial scholars moreover observed that traditional narratives of modernity ignore the colonial context in at least two ways. Firstly, they discount the European or 'western' politics of power and submission that were implemented alongside the many ways of appropriation and transformation that altered the meaning of the concept as a result of the imperial encounter. Secondly, they also destroyed the popular image of colonialism as a civilizing mission or benevolent activity of modernization and development, and highlighted the violence and hypocrisy of the colonial project. The latter even came to be viewed as a prelude to the Holocaust, which became the pinnacle of Europe's twentieth century and of 'the modern project' itself; it has even become a constituent element of the way the EU imagines European identity today. ${ }^{7}$ Emphasizing the 'Dark Side' of modernity has become a popular trope indeed.

The concept of 'multiple modernities' emerged in the I990s as one sociological and philosophical answer to the problem of the multiple ways in which societies over the world gave shape to it (Shmuel Eisenstadt; Charles Taylor). ${ }^{8}$ However, as Arif Dirlik and Volker H. Schmidt observed, ${ }^{9}$ the concept in fact only confirms the western origins of modernity, while other scholars deny these exclusively western roots, referring even to 'lost modernities' originating in non-western 
societies, rejecting the chronological straitjacket associated with European modernity. ${ }^{\text {Io }}$ The result of this questioning may lead to the impression of a Babylonian confusion, and give way to the conclusion that the concept has become virtually meaningless; many if not most historians effectively abandoned the concept altogether or follow the approach advocated by Frederick Cooper to focus on the use of the term in different contexts ("[Scholars] should ask how [modernity] is being used and why'). ${ }^{11}$ Certainly though this solution also has obvious disadvantages - what to do with movements that reject modernity or at least some political interpretations of the term, such as fascism or ultramontane Catholicism? They have been reinterpreted as modern phenomena, aiming at a radical transformation of the world, albeit in their own terms. In this respect a new generation of historians in the wake of Cooper has developed their own 'cosmopolitan' history (without referring to that term though) by focusing on how European concepts have interacted and diffused globally, an approach which situates Europe in a network of permanent influences and interactions in which the question of origin evaporates as largely irrelevant. ${ }^{12}$ What does appear from all these observations in the first place, however, is that the concept is all but neutral and always imbedded in a context of power, appropriation and interpretation, and hence should be properly historicized and contextualized, including our own use of it.

In his definition of modernity Gerard Delanty focuses particularly on human agency, the ability 'to transform the world in the image of a possible future', encompassing politics, economics, as well as culture. This easily leads to a Whiggish representation of history as one of progress, all the more so as history is considered, as is the case here, as a 'learning process' (referring to Jürgen Habermas) even if it allows for 'regressions' (I 8) - indeed hardly compatible with a history that focuses on the 'dark sides' of modernity. Nevertheless, following Ulrich Beck, Anthony Giddens and Peter Wagner's emphasis on reflexivity, Delanty ascribes to modernity a fundamental duality, of always oscillating 'between communicative rationality and instrumental rationality, between democracy and capitalism, between autonomy and power' (I9). Illustrative is the (not very surprising) observation that Eurocentrism and the criticism aimed at Eurocentrism became both associated with modern European culture (e.g. I 82; I52-I 53). From this perspective Delanty understands modernity as a cultural model that 
derives from different ideas and social sectors, expressing themselves in different ways. Liberal democracy, communism and fascism hence all offered rivalling projects of modernity in the twentieth century (I9; 23; 2 I 5-242).

This approach may dissociate modernity from Europe. Though Delanty indeed affirms this conclusion (20), it rather conflicts with his argument that forms of modernity are not entirely open, as the "various forms modernity have taken are determined by the relationship between capitalism, the state and civil society' (I9-20), which rather locates the origin of modernity in a specific time and a specific place. Moreover, a feature of modernity being that it understands itself to be modern, the encroachment within a particular intellectual tradition and its associated language is further emphasized. Hence modernity, or at least European modernity, is the product of a particular European conjuncture clearly establishing itself since the sixteenth century in Europe, which then spread over the world. Consequently, Delanty follows Peter Wagner (and others, such as Arif Dirlik and Volker Schmidt) in speaking of 'varieties of modernity' rather than of 'multiple modernities' (20). Modernity then becomes 'a singular condition while taking multiple forms' (24).

More interesting from my perspective is that Delanty also forcefully pleads for the consideration of the global context as an essential part of any social analysis. The concept of critical cosmopolitanism as defined in the introductory chapter, focusing on openness to the world and the willingness to change in the interaction with others, recognizing otherness in oneself, looks more than promising in this respect (27). More than his ambiguous definition of modernity, critical cosmopolitanism appears indeed open-ended, culture-free and 'reflexive' and, hence, very suitable for historical analysis.

\section{A Cosmopolitan History?}

Delanty develops his argument through a largely chronological or epochal structure based upon a vast and erudite assessment of historical and social science literature. His main point is to clarify the development of a specific societal model 'the chief characteristic of which was that neither the state nor capitalism entirely dominated society' 
(2I), creating the conditions in which a critical modernity could arise. Although he explicitly recognizes the discontinuities and breaks, this structure almost inevitably produces a narrative of progress and development, which in practice largely mirrors the most traditional histories of the emergence of a European idea: he traces the origins of European modernity in Greco-Roman and Judaic legacies and Christianity, further emphasizing the importance of the Renaissance, humanism and the Enlightenment, and the rise of the nation-state. Howerver, Delanty adds an important dimension to these stories of origin by including trans-civilizational influences and interactions with other, mainly neighbouring cultures. This cosmopolitan orientation entices him to include a discussion on the 'Byzantine legacy' and the significance of the Islamic world in the foundation of Europe's modernity - certainly a welcoming and refreshing perspective. Rather puzzling though is that Germanic and Celtic people apparently did not contribute significantly to the formation of modern Europe, although they did develop very relevant ideas about the organization of society that left their mark on the medieval world and indirectly on later developments. Perhaps in his eyes they did not constitute a 'civilization', as Delanty explicitly frames his history of Europe as a history of European civilization, reviving a concept that is rather contested by most world historians today. It also reminds one of another contested concept, that of 'peoples without history'. Apparently non-literary peoples counted among these as well. Incidentally it seems that contemporary Judaism is also excluded from the main European narrative, as the Judaic legacy is, as usual, relegated to the world of the Old Testament, though Delanty occasionally mentions Jews as mediators between antique and modern systems of knowledge - for example referring to Jews who kept ancient Greek texts and translated them from Arabic.

In this context, Delanty refers to the work of the French philosopher Rémi Brague (48) who considers the eclectic nature of European society to be one of its features. That certainly is the case. However, at the same time the reference to Brague is also rather odd as the latter emphasizes the fundamental break between the medieval and the old Roman world: for Brague the core of Europe's history is not a continuation of an ancient past of Greek and Roman greatness, but in contrast a radical departure from it. Central in Brague's assessment is the longing for the power and greatness of Antiquity: its shadow is not so much a legacy 
as a rivalry, leading to forms of appropriation of what is fundamentally alien. Brague thus rejects the linear connection between Roman and Greek Antiquity and (medieval) European culture. For the French philosopher incidentally this constitutes the fundamental difference with the Byzantine and even the Islamic worlds, which in his eyes constitute a continuation of Antiquity and thus do not share this alterity. ${ }^{13}$

This brings me to the core of my critique of Delanty. Although he acknowledges that cosmopolitanism is not a European singularity and that other civilizations could be even more cosmopolitan, he arguably overstates his case with regard to Europe. As I explain at length elsewhere, Europe has a long history that hardly qualifies as one of openness and inclusion. ${ }^{14}$ In contrast, most of its history is particularly exclusive, a 'persecuting society' (R.I. Moore) in the Middle Ages as well as much later, in which non-Christians were hardly tolerated, as especially Jews experienced so many times throughout European history. Certainly, as traditional (Eurocentric) histories of science argue (followed by Delanty), medieval monks and scholars studied ancient texts and developed a sense of critique and curiosity that grew into the foundation of modern science. However they ignore that non-western and non-Christian scholars were not welcome at its centres of learning, unlike most societies of South and East Asia: learned Indians or Chinese, if they had ventured so far into the barbaric northwest, would have had no chance of being promoted to the highest ranks of scholarship or councillorship such as a Marco Polo or the famous Jesuits at Chinese imperial courts: they would most likely have ended up hanged. Even Arab merchants did not continue their business travels into the European interior. Certainly, Europeans did learn a lot from other civilizations, but it was not because they were so welcoming and open towards the other. When Europeans dominated the world from around I 800 onwards, as Chakrabarty has reminded us, they actually ousted non-western forms of knowledge. ${ }^{15}$ That traditional European historiography on the 'rise of the West' has largely ignored the significance of non-European science and technology - what Jack Goody called The Theft of History - is actually an expression of this exclusionary practice. ${ }^{16}$ This does not mean that some Europeans were not driven by genuine curiosity and cultural forms and knowledge could not find their way into Europe, only that society was organized in a way that did not allow 'others' to be part of it and contribute as such to its development: 
its borders remained guarded and controlled. And scientific curiosity by all means is not a privilege of Europeans.

The chapter on the relationship between Europe and Islam illustrates the strength as well as the fundamental weakness of Delanty's approach. It is quite accurate in demonstrating the interaction that existed between the Islamic and the European Christian worlds, showing that the impact of Islamic culture on Europe was far greater and important than has often been assumed, that the relationship itself was far more complex than one of simple opposition and that this also changed over time. Delanty in this sense admirably assesses the different ways of imagining the 'other' in terms of attraction and repulsion. However, in his eagerness to state his case for a cosmopolitan Europe, Delanty pushes his argument too far, ignoring the politics of exclusion, isolation and superiority that equally, if not more, characterized Europe for most of its existence, not only during the heyday of colonialism - which is hardly touched upon.

Focusing on the 'positive' dimensions of European history leads to rather distorted historical representations also in other parts of the book. So Delanty discusses the formation of world fairs and exhibitions in the nineteenth and early twentieth century as places for nation-building that nevertheless facilitated cosmopolitan interactions. This they certainly were, but they also particularly emphasized European superiority and displayed a racist division of the world. Though they cannot be reduced to this - in that sense I agree with Delanty -, the interactions that they generated cannot be simplified as signs of Europe's openness to the world either. Likewise, while arguing that the Enlightenment thinkers did not just create an Orientalist opposition to the East, Delanty underestimates the enlightened and modern drive to classification and ordering that, even if inspired by genuine interest, did constrain the other.

Chapter nine of the book, focusing on the interplay between nationstates and empires, nevertheless includes some penetrating insights about the importance of imperialism, colonialism and racism that pervaded European societies. Delanty actually demonstrates a deep understanding of the complex relationships between colonies and metropoles, even recognizing the possible contribution of others to European modernization and democratization - he explicitly refers to the American Revolution and the Haitian slave revolt. But in the end the significance of European imperialism is the diffusion of European ideas about 
human rights and democracy. If 'Europe was shaped by its colonies in both positive and negative ways' ( I94) the balance for Delanty clearly tips to the positive side - all the more so as this paragraph remains quite short in the whole book.

For a book that aims at offering a cosmopolitan alternative to Eurocentric assessments of European history, Formations of European Modernity pays little attention to the perspective of the 'other': interactions are viewed from a European perspective. In particular nonEuropean representations of Europe do not figure as part of the interaction. How Muslims perceived Europe for example remains unexplored, though one can wonder if an identity is not also made by the perspective of others. The lack of outside perspectives returns in the failure to introduce a relevant comparative assessment. This for example comes to the fore in his discussions on European diversity. As many others, Delanty emphasizes European diversity as one of its main features, rejecting a popular but overly simplistic view of an age-old Europeanization. Actually Delanty is particularly effective in discussing Europe's diversities, especially regional ones. He recognizes that they are based on discontinuities and that there was no continuous common alterity against which Europe set itself off. Importantly, not even Islam functioned as an inimical other: the relationship was far more complex and variable. Nevertheless this emphasis on European diversity, popular as it is, is puzzling from a global comparative perspective. Is Europe really more diverse than other parts of the world? More than India, with its thousands of tongues, where diversity perhaps constitutes the sole common experience of the region before the coming of the British? ${ }^{17}$ Or more than Southeast Asia, sometimes referred to as a 'noodle box' because of its intermingling of ethnicities, languages and religions? I don't think so: pushing an argument formulated by the late Tony Judt beyond its initial intention, I would contend that Europe, especially Western Europe, should be considered uniquely obsessed with diversity while being remarkably homogenous in terms of language, ethnicity and religion. ${ }^{18}$ Nevertheless, Delanty does recognize homogenizing forces in Europe's early modern history as well (e.g. I37-I42), and actually his discussion of the tension between homogenization and pluralization is particularly nuanced and insightful.

A lack of comparative perspective makes some arguments appear rather gratuitous. Claiming that Europe was unique because it "was 
never fully integrated from "above" by the state or by an ecclesiastical authority' (I45) for example leaves the reader wondering on what grounds statements like this one are based. Is there some comparison involved with China, which is indeed the result of centuries of Han Chinese political and cultural imperialism? With India, which was unified by the British; or with South-East Asia that has never been unified in any way? With Latin America perhaps, divided notwithstanding Spanish-Portuguese colonialism? As regards the statement that Europe was unique because it 'was never fully integrated from above' one could easily make a case for the opposite. Europe indeed was considered a unity at least by some elites already since the eleventh, twelfth century if not earlier: Europe shares a common heritage of Christendom, with its innate Church-State conflict, which gave way to the idea of Europe as an escape from this division, a longing for a lost unity that never existed. ${ }^{19}$ Ideas about European unity emerged from various circles, but if the latter have one thing in common it is that they were driven by political and cultural elites, rather closely connected to the centres of power. In contrast of what perhaps may be a popular myth, they certainly did not emerge from a popular base. This suggests a rather important degree of 'integration' from above.

Likewise one wonders on what basis other statements about the specificity of Europe are made, as the one with regard to the core of the European social mode: 'The specificity of Europe as a world historical region does not consist in democracy, human rights, republican government liberty, freedom - all of which have been regarded as the core of European values - but in the ways in which these ideas have been taken up in social struggles as well as in the institutional forms that followed from such struggles' (274). I am sure there is much truth in this conclusion, if only because 'democracy, human rights, republican government liberty, freedom' have been pursued, albeit in different forms, in other civilizations as well, and Europe has created a (or several types of) welfare state(s). However, I would hesitate to affirm with any confidence that the longing for social justice was so exclusively European (at least if one adopts a rather open definition of social justice). Moreover, while the concept has been interpreted in quite divergent ways within Europe also, not all movements in European history placed social justice on top of their agenda. But again the cosmopolitan dimension apparently does not imply a global comparative discussion. I cannot help that I 
automatically recalled Chakrabarty's comment on yet one more of these theories to "embrace the entirety of humanity ... in relative, and sometimes absolute ignorance of the majority of mankind' ${ }^{20}$ Modernization theories invariably qualify for this qualification - the experiences and perspectives of others finally do not matter.

\section{The Uses of History}

The last chapter, published earlier as a LSE working paper, assesses European history in terms of conflicting narratives of heritage. The first and most common one advanced is that of a shared political legacy, with deep roots in history, though Delanty emphasizes that the content of this shared heritage is in itself disputed. In a powerful paragraph he again refers to the tension between unity and diversity, warning against narratives that overly emphasize unity without taking into account the historical diversities. While admitting the inclusion of contesting memories may be 'a necessary step', he strongly opposes a narrative that focuses on the memories of victims and the persecuted, prohibiting a common European memory, as 'it cannot be the basis for the future which requires positive models of identification' (298). For Delanty the cosmopolitan heritage of interaction and dialogue in contrast may constitute such a positive source of identification and may help Europe 'to come to terms with its own cultural and political diversity', concluding though that it may be time for Europe 'to move beyond its past' (299). One may wonder if Delanty's overly positive representation of Europe's cosmopolitan history, of 'model Europe', really is what the continent needs. Especially in Asia the EU's complacent attitude with regard to human rights, its self-proclaimed moral superiority, constitutes a source of permanent irritation, even if this sometimes may be an easy way of condoning human rights abuses as well. Moreover, one could make a case that Europe should rather face its past 'as it really was' in order to reconnect and reconcile with others who were often victims of its imperial ambitions as well as with itself - God knows how many scars still linger because of an unresolved past.

As regards Europe itself, the interpretation of the current malaise with dealing with diversity, expressed in xenophobia and racism, as resulting from insecurity and uncertainty, but also as "symptomatic of a 
wider cultural crisis in the values on which Europe is based' (304-305) could be challenged. Indeed, a whole different picture emerges when one understands Europe's problems with racism and xenophobia in its deep-rooted longing for similarity and homogeneity (what the German historian Thomas Mergel calls Europe's Sehnsucht nach Ähnlichkeit), which had its parallel in its exclusive attitude cherishing feelings of superiority and difference towards other civilizations. ${ }^{21}$ Paradoxically such an alternative assessment may lead to a more optimistic prospect, as it may suggest that Europe finally is starting to move away from its troubled past and towards a more inclusive society: the current crisis may then rather be interpreted as a rear-guard fight. I do not know: historians make such bad prophets, though not necessarily worse than more confident colleagues from other disciplines.

This brings me to some comments on the use of history. Gerard Delanty considers the work of historians as poor value for a contemporary European self-understanding, either because they overemphasize the 'dark side' of European history or, mostly, because they shy away from theory and 'grand narratives' - as in Norman Davies' Europe, a History (I996). Even worse, some even deny the existence of a common European history claiming 'that there are only different constructions of Europe which means many different things to many different people' (292, referring to the work of John G.A. Pocock) ${ }^{22}$ Although a fervent proponent of interdisciplinarity myself, I admit that I was never as acutely aware of the different conceptual expectations between sociologists and historians than after reading this 'historical and political sociology of Europe'. Historians indeed do not study history with an eye to the present, not even with the intention of explaining it - the idea of history as magistra vitae has already been abandoned since the I960s. Historians are well aware though that they inevitably write from and are embedded in the present. It is in that sense that their work, even if related to an ancient past, may be relevant to the present after all, by demonstrating the differences as well as the similarities. The latter is not necessarily the same as continuity: understanding discontinuities is as least as important in understanding the present as continuities. ${ }^{23}$ But perhaps the difference is not so much between historians and sociologists as between two modes of thinking: between those who emphasize Verstehen (understanding), as Hannah Arendt understands it, and those 
who have a case to defend. Delanty clearly belongs to the latter. But who can maintain that Verstehen has no relevance to the present?

\section{Conclusion}

Certainly Formations of European Modernity is in many ways an impressive achievement, also from a historical perspective. It is based upon a huge body of literature from a wide variety of angles. Some assessments are particularly nuanced and insightful. Though I paid only scant attention to it, Delanty's assessment of European spatialities the regional diversities and the importance of transnational connections transcending the nation-state in modern times - offers a different and exciting way of imagining Europe. Also his emphasis on interactions is actually what a critical history of Europe requires. Hence the book's cosmopolitan ambition may still figure as a challenging eye opener to many, especially those readers who are not familiar with postcolonial studies. Nevertheless, the book falls short of expectations. It overemphasizes the European 'openness' for change and global interaction in history, it hardly includes the experience of the 'other', and contains a complacent narrative that glorifies Europe's role in the world. Delanty does recognize Europe's imperial and colonial past and its racism, but to a large extent downplays its importance and turns it into a factor that stimulated its modernization. Referring to Gurminder Bhambra's strident critique of the reflexive modernity of Habermas and Derrida quoted in the epigraph, one could observe furthermore that it does not appear in this book as an episode which figures centrally in the learning process that is supposed to animate the history of European modernity either. Racism and colonialism themselves of course were also the results of 'lessons' that were drawn from history. What happened is that Delanty's presentation of Europe's cosmopolitan history has become too much of a reflection of the present: finally it almost says more about the contemporary sociological preoccupation with globalization and cosmopolitanism than about the past. Paradoxically this means that it is less illuminating of the present as well, as how can one properly understand the present if one misinterprets its past?

This observation may sound particularly awkward for a book that places reflexivity and critical cosmopolitanism at the core of the 
modern project. Dipesh Chakrabarty once famously called for 'provincializing Europe' - meaning 'to write into the history of modernity the ambivalences, contradictions, the use of force, and the tragedies and ironies that attend it' (43). Although Delanty to some extent includes them into his narrative of European history, in the end it remains marginal to his overall argument. Hence the impression of deep disappointment prevails after reading this book - this 'cosmopolitanism' turns out to be quite Eurocentric. The new global history as practiced by historians such as Christopher Baily, Sebastian Conrad, Frederik Cooper, Matthias Middell, Jürgen Osterhammel and Sanjay Subrahmanyam, among others, in my view offers better venues to arrive at a cosmopolitan, non-Eurocentric history of Europe, avoiding the complacent overemphasizing of Europe's highly questionable 'openness' and reflexivity. However, in contrast to Delanty's definition of modernity which starts as an open-ended one but gradually solidifies into the traditional European singularity, in their work European modernity seems melting into air as does the question of its origins. But as Chakrabarty and even Cooper concede, I am not sure it is possible to dispose of a concept that has put such a deep mark on our history and imagination. A critical cosmopolitan approach as Delanty advocates may in the end offer a promising way to study European history, on condition of adopting a more critical global perspective and a more open attitude towards the complexities and paradoxes of the European experience in its totality.

\section{Notes}

Writing a review of Gerard Delanty's book Formations of European Modernity. A Historical and Political Sociology of Europe (Basingstoke, 2013) and discussing his ideas in class was an assignment in the Master of European Studies: Transnational and Global Perspectives at the KU Leuven. The book led to some passionate debates. Some students made particularly insightful reviews, some left a trace in this essay. I would particularly like to thank Gloria Ghéquière, Melissa Grünewig, Elisa Masschelein, as well as the anonymous reviewers of this essay. They do not necessarily share my ideas though.

I Gurminder K. Bhambra, 'Postcolonial Europe: Or, Understanding Europe in Times of the Postcolonial', in Chris Rumford (ed.), The SAGE Handbook of European Studies (London, 2009) 69-85, 80. 
2 Gerard Delanty, Inventing Europe: Idea, Identity, Reality (Basingstoke, I995).

3 Gerard Delanty, 'Nationalism and Cosmopolitanism: the Paradox of Modernity', in Gerard Delanty and Krishan Kumar (eds), The SAGE Handbook of Nations and Nationalism (London, 2006) 357-368, 357; Gerard Delanty, The Cosmopolitan Imagination: The Renewal of Critical Social Theory (Cambridge, 2009).

4 Resolution of the Republican National Committee, Chicago, 6-8 August, 20I4, quoted in Catherine Gewertz, 'Republican National Committee Condemns New AP History Framework', on I I August 2014 (http://blogs. edweek.org/edweek/curriculum/20 I4/o8/college_board_statement_on_ ap.html) as well as in James Grossman, 'The "Proper Study of History": What the Public Thinks about Historical Thinking', Perspectives on History, 52:7 (Oct. 20I4) 7-8 (expressing the reaction of the American Historical Association).

5 Esp. Mark Mazower, Dark Continent: Europe's Twentieth Century (New York, I998), Christian Meier, From Athens to Auschwitz: The Uses of History (Cambridge, 2005) or Walter D. Mignolo, The Darker Side of the Renaissance: Literacy, Territoriality and Colonization (Ann Arbor, I995; Walter Mignolo, The Darker Side of Western Modernity: Global Futures, Decolonial Options (Durham, 20II). For a historical approach of the same criticism, see Holger Nehring and Helge Pharo, 'A Peaceful Europe? Negotiating Peace in the Twentieth Century', Contemporary European History 17:3 (2008) 277-299.

6 Zygmunt Bauman, Modernity and Ambivalence (Cambridge, I99I); Jeffrey C. Alexander, The Dark Side of Modernity (Cambridge, 2013).

7 Gurminder K. Bhambra, Rethinking Modernity: Postcolonialism and the Sociological Imagination (Basingstoke, 2007). On the Holocaust as a constituent part of European identity and the subsequent debates about alternative sources of identity see Claus Leggewie, Der Kampf um die europäische Erinneriung. Ein Schlagfeld wird besichtigt (Munich, 20 I I).

8 For an introduction see Gerhard Preyer's 'Introduction: The Paradigm of Multiple Modernities' to the special issue 'Shmuel N. Eisenstadt: Multiple Modernities - A Paradigm of Cultural and Social Evolution' of ProptoSociology. An International Journal of Interdisciplinary Research 24 (2007) 5-I8.

9 Arif Dirlik, Global Modernity: Modernity in the Age of Global Capitalism (Boulder, Co., 2007) 90; Volker H. Schmidt, 'Multiple Modernities or 
Varieties of Modernity?', Current Sociology 54:I (2006) 77-97; Peter Wagner, Modernity: Understanding the Present (Cambridge, 2012).

Io Alexander Woodside, Lost Modernities: China, Vietnam, Korea, and the Hazards of World History (Cambridge, Mass., 2006).

I I Frederick Cooper, Colonialism in Question: Theory, Knowledge, History (Berkeley, 2005) I I 5. See also 'Roundtable: Historians and the Question of "Modernity" in the American Historical Review I I 6:3 (20 I I) 63 I-75I.

I 2 See e.g. Sebastian Conrad, 'Enlightenment in Global History: A Historiographical Critique', American Historical Review, I 7 (2012) 999I027 (and the references in the previous note).

I3 Rémi Brague, Europe, la voie romaine (Paris: Criterion, I992) (English transl. Eccentric Culture: A Theory of Western Civilization, trans. Samuel Lester (Notre Dame, 2009)).

I4 Patrick Pasture, Imagining European Unity Since 1000 AD (Basingstoke, forthcoming 2015).

I5 Chakrabarty, Provincializing Europe, 5, 28ff.

I 6 Jack Goody, The Theft of History (Cambridge, 2006).

I7 Comp. K.N. Chaudhuri, Asia before Europe: Economy and Civilisation of the Indian Ocean from the Rise of Islam to 1750 (Cambridge I99I); Pasture, Imagining European Unity. The Indian census recognized I,652 different languages in India (including languages not native to the subcontinent) in I96I; the I99I census limits the amount at a total of I22 languages and 234 'mother tongues' of at least Io,00o speakers. http://www.censusindia. gov.in/Census_Data_20oI/Census_Data_Online/Language/Statement I . htm. The EU currently recognizes 35 official languages; there are not many languages that do not benefit from official recognition.

I 8 Comp. Tony Judt, A Grand Illusion? An Essay on Europe (New York and London, 20II) 46: 'Indeed, drawing distinctions among and between themselves has been one of the defining obsessions of the inhabitants of the continent'.

I9 I have developed this and the following argument in Pasture, Imagining European Unity.

20 Dipesh Chakrabarty, Provincializing Europe: Postcolonial Thought and Historical Difference (Princeton, 2000) 29.

2 I Thomas Mergel, 'Die Sehnsucht nach Ähnlichkeit und die Erfahrung der Verschiedenheit. Überlegungen zu einer Europäischen Gesellschaftsgeschichte im 20. Jahrhundert', Archiv für Sozialgeschichte 49 (2009) 4I7-434. 
22 J.G.A. Pocock, 'Deconstructing Europe', in Peter Gowan and Perry Anderson (eds), The Question of Europe (London, I997) 297-3 I7; J.G.A. Pocock, 'Some Europes in their History', in Anthony Pagden (ed.), The Idea of Europe: From Antiquity to the European Union (Cambridge, 2002) 55-7I.

23 See also Jo Guldi and David Armitage, The History Manifesto (Cambridge, 20I4) for a recent plea for historians to be relevant.

\section{About the Author}

Patrick Pasture is Professor of History and Co-Director of the Master in European Studies: Transnational and Global Perspectives at KU Leuven (Belgium). Having worked on labour history as well as the social history of religion, his current research and publications focus on the interplay between religion and society, privileging global contexts and long-term perspectives. His latest book Imagining European Unity Since 1000 AD will be published by Palgrave Macmillan in June 20 I 5 . E-mail: Patrick.Pasture@arts.kuleuven.be 